\title{
Potensi Kolonisasi Mikoriza Arbuskular dan Cendawan Endofit dan Kemampuannya dalam Pengendalian Layu Fusarium pada Bawang Merah
}

\section{Colonization Potential of Arbuscular Mycorrhiza and Endophytic Fungi and Its Effectiveness in Control Fusarium Wilt on Shallot}

\author{
Mei Lita Fitriani, Suryo Wiyono*, Meity Suradji Sinaga \\ Institut Pertanian Bogor, Bogor 16680
}

\begin{abstract}
ABSTRAK
Layu Fusarium merupakan penyakit penting pada bawang merah (Allium cepa var. aggregatum) yang disebabkan oleh Fusarium oxysporum f.sp. cepae. Pada penelitian ini, isolat biokontrol potensial cendawan endofit dan mikoriza diuji kemampuan kolonisasinya secara tunggal dan kombinasi untuk menekan perkembangan penyakit layu Fusarium. Percobaan dilakukan menggunakan rancangan acak lengkap dengan 8 perlakuan dan 5 ulangan. Kemampuan menekan patogen diamati dari persentase kolonisasi agens biokontrol, periode laten penyakit, insidensi penyakit, laju infeksi, dan area under the disease progress curve (AUDPC). Agens biokontrol yang diujikan berhasil bersimbiosis dengan akar tanaman bawang merah. Aplikasi tunggal mikoriza arbuskular paling baik dalam memengaruhi pertumbuhan tanaman dan menekan perkembangan penyakit layu fusarium pada bawang merah dengan periode laten penyakit terpanjang 21 hari dan menurunkan insidensi penyakit hingga $40 \%$.
\end{abstract}

Kata kunci: agens biokontrol, kombinasi agens biokontrol, mekanisme antagonis

\begin{abstract}
Fusarium wilt is an important disease on shallot (Allium cepa var. Aggregatum) due to Fusarium oxysporum f.sp. cepae. The research aimed to study colonization of arbuscular mycorrhiza and endophytic fungi, and their biocontrol performance against fusarium wilt disease of shallot. The experiment was performed using a completely randomized design with 8 treatments and 5 replications. The effectiveness of biocontrol agents on the progress of fusarium wilt was observed from the percentage of agent biocontrol colonization, disease latent periode, disease incidence, rate of infection, and area under disease progress curve. The biocontrol agent tested successfully symbiotic in the root tissue of shallot. The single application of arbuscular mycorrhizal showed the best influence on plant growth and suppressing the progress of fusarium wilt in shallots with the longest disease latent period at 21 days and decreasing disease incidence up to $40 \%$.
\end{abstract}

Key words: antagonism mechanism, biocontrol agent, biocontrol combination

*Alamat penulis korespondensi: Departemen Proteksi Tanaman, Fakultas Pertanian, Institut Pertanian Bogor. Jalan Kamper, Kampus IPB Dramaga, Bogor 16680.

Tel: 0251-8629364, Faks: 0251-8629362,Surel: suryowi@apps.ipb.ac.id 


\section{PENDAHULUAN}

Saat ini, penyakit layu Fusarium menjadi masalah utama yang merugikan bagi petani bawang merah (Allium cepa var. aggregatum). Penyakit layu ini disebabkan oleh Fusarium oxysporum f.sp. cepae saat ini menjadi masalah dominan pada tiap sentra produksi bawang merah di Indonesia dan telah dilaporkan terjadi di banyak negara (Fadhilah 2014). Layu fusarium menyebabkan busuk pangkal batang yang dapat menurunkan hasil umbi hingga 50\% (Wiyatiningsih et al. 2009). Tondok (2001) melaporkan kerusakan akibat serangan $F$. oxysporum pada bawang merah dapat mencapai $100 \%$.

Petani mengendalikan penyakit layu fusarium menggunakan fungisida atau mengumpulkan dan memusnahkan tanaman sakit. Teknik pengendalian lainnya yang dilakukan antara lain rotasi tanaman, penggunaan tanaman resisten, dan solarisasi tanah. Teknik pengendalian alternatif lainnya yang dapat dikembangkan ialah pengendalian secara hayati menggunakan agens biokontrol.

Mikoriza arbuskular (MA) dan cendawan endofit merupakan agens biokontrol yang dapat digunakan untuk mengendalikan penyakit layu fusarium pada bawang merah. MA hidup secara biotrop dan berkoloni pada sistem perakaran hingga tanaman dewasa dan dapat memberikan pertahanan pada akar tanaman terhadap patogen tular tanah (AlAskar dan Rashad 2010). Penggunaan MA dan cendawan endofit sebagai pengendali patogen tular tanah telah banyak dilaporkan, di antaranya untuk mengendalikan Sclerotuim rolfsii dan F. solani (Ozgönen et al. 2010; AlAskar dan Rashad 2010).

Cendawan endofit yang diisolasi dari bawang merah dapat menekan perkembangan penyakit busuk umbi pada bawang merah dengan tingkat efikasi sebesar $61.70 \%$ dan $63.83 \%$ (Zulaika 2014). MA dengan cendawan endofit hifa gelap dilaporkan secara alami bersimbiosis dalam jaringan akar yang sama pada tanaman bawang merah (Priyadharsini et al. 2012). Cendawan endofit dan MA berkoloni di dalam akar tanaman secara interseluler sehingga diharapkan berkolonisasi bersama dan mampu menekan perkembangan penyakit layu fusarium. Penelitian ini bertujuan mengevaluasi kolonisasi dan keefektifan mikoriza arbuskular dan cendawan endofit baik secara tunggal maupun kombinasi terhadap penyakit layu fusarium dalam mengendalikan F. oxysporum f. sp. cepae pada bawang merah.

\section{BAHAN DAN METODE}

\section{Penyiapan Mikoriza Arbuskular, Cendawan Endofit dan Cendawan Patogen}

Formula mikoriza arbuskular (MA) diperoleh dari Balai Pengkajian Bioteknologi, Badan Pengkajian dan Penerapan Teknologi (BPPT), Pusat Pengembangan Ilmu Pengetahuan dan Teknologi (Puspiptek), Serpong. Tiap gram inokulum mengandung \pm 60-70 spora, dengan formulasi campuran empat spesies MA, yaitu Gigaspora sp., Glomus putih, Glomus coklat, dan Acaulospora sp.

Isolat cendawan endofit (CE) yang digunakan dengan kode PAP4 dan PUP1 merupakan isolat koleksi Laboratorium Mikologi Tumbuhan, Departemen Proteksi Tanaman, Fakultas Pertanian, Institut Pertanian Bogor. Isolat diremajakan pada medium potato dextrose broth (PDB). Penyiapan suspensi $\mathrm{CE}$ dilakukan dengan menumbuhkannya pada PDB $10 \mathrm{~mL}$, kemudian dikocok dengan shaker (Eyela Multishaker) pada kecepatan 130 rpm selama 7 hari. Suspensi CE yang telah menggumpal, disaring dan dibilas dengan air destilata sebanyak 3 kali dan dipindahkan ke dalam $100 \mathrm{~mL}$ air destilata untuk dihancurkan menggunakan homogenizer (IKA ULTRATURRAX T18 Basic) dengan kecepatan 3500-24 000 rpm selama 8 menit. Kerapatan $\mathrm{CE}$ yang digunakan ialah $10^{5} \mathrm{cfu} \mathrm{mL}^{-1}$.

Isolat $F$. oxysporum f. sp. cepae koleksi Laboratorium Mikologi Tumbuhan, Departemen Proteksi Tanaman, Fakultas Pertanian, Institut Pertanian Bogor merupakan hasil isolasi dari tanaman bawang merah yang memiliki gejala busuk umbi dan layu fusarium yang berasal dari Tegal (Jawa Tengah). Peremajaan F. oxysporum f. sp. cepae dilakukan pada medium agar-agar 
dekstrosa kentang (ADK). Perbanyakan $F$. oxysporum f. sp. cepae dilakukan dengan menumbuhkan F. oxysporum f. sp. cepae pada medium beras steril. Beras direndam dalam air bersih selama \pm 12 jam, kemudian dicuci dan dikeringanginkan. Sebanyak $300 \mathrm{~g}$ beras dimasukkan ke dalam plastik tahan panas dan disterilisasi menggunakan autoklaf pada suhu $121{ }^{\circ} \mathrm{C}$ dengan tekanan $1 \mathrm{~atm}$. Isolat $F$. oxysporum f. sp. cepae diambil menggunakan cork borer diameter $5 \mathrm{~mm}$ sebanyak 5 plak dan ditumbuhkan ke dalam medium tersebut dan diinkubasi selama 30 hari pada suhu ruang.

Suspensi $F$. oxysporum f. sp. cepae dibuat dengan menghaluskan $100 \mathrm{~g}$ isolat F. oxysporum f. sp. cepae berumur 30 hari dan dicampur dengan $100 \mathrm{~mL}$ air destilata. Suspensi disaring dan kerapatan propagul dihitung hingga mencapai $10^{5} \mathrm{cfu} \mathrm{mL}^{-1}$.

\section{Uji Kemampuan Kolonisasi dan Keefektifan} Mikoriza Arbuskular dan Cendawan Endofit dalam Menekan $F$. oxysporum f. sp. cepae secara in Planta

Benih bawang merah varietas Tuk-tuk disemai pada medium tanam steril. Benih bawang merah yang telah disterilisasi permukaan kemudian diberi perlakuan seperti tertera pada Tabel 1. Perlakuan CE dilakukan dengan merendam benih bawang merah dalam suspensi CE selama \pm 12 jam. Selanjutnya pada perlakuan aplikasi mikoriza arbuskular (MA), benih bawang merah steril ditanam pada medium semai yang dicampur dengan 10 g MA tiap pada kedalaman $3 \mathrm{~cm}$. Perlakuan kontrol dilakukan dengan perendaman benih menggunakan air destilata. Sebanyak 5 larik benih bawang merah disemai dalam baki semai selama \pm 4 minggu kemudian dipindah tanam ke pot plastik dengan ukuran $25 \mathrm{~cm} \times 25 \mathrm{~cm}$. Medium tanam yang digunakan ialah tanah, arang sekam, pupuk kandang dengan perbandingan $1: 1: 1(\mathrm{~b} / \mathrm{b})$ yang telah disterilisasi dan diangin-anginkan selama 3 hari.

Tanaman bawang merah berumur 2 minggu setelah tanam (MST)-termasuk tanaman kontrol-kemudian diberikan perlakuan patogen dengan meneteskan $1 \mathrm{~mL}$ suspensi patogen $F$. oxysporum f. sp. cepae $\left(10^{5} \mathrm{cfu} \mathrm{mL}^{-1}\right)$ di setiap lubang tanam. Tanaman bawang merah dipelihara selama 60 hari dan dilakukan pengamatan gejala layu fusarium.

\section{Pewarnaan Akar Bawang Merah}

Pewarnaan akar dilakukan untuk melihat struktur cendawan dalam jaringan akar tanaman sehingga mempermudah pengamatan kolonisasi oleh agens biokontrol. Pewarnaan akar yang dilakukan menggunakan metode yang digunakan oleh Brundrett et al. (1996) yang dimodifikasi pada pewarna vinegar quink red 5\%. Akar bawang merah dibersihkan dan dimasukkan ke dalam botol kaca. Akar bawang merah selanjutnya diproses secara berurutan, yaitu clearing dan staining. Clearing dilakukan dengan cara merendam akar dalam larutan $\mathrm{KOH} 10 \%$ (w/v) dan dipanaskan pada suhu $60{ }^{\circ} \mathrm{C}$ hingga $90{ }^{\circ} \mathrm{C}$ selama $10-30$ menit, kemudian dicuci dengan air mengalir hingga akar jernih. Tahapan selanjutnya ialah pewarnaan akar dengan merendamnya dalam larutan pewarna selama 12 jam.

Tabel 1 Perlakuan mikoriza arbuskular dan cendawan endofit pada akar bawang merah

\begin{tabular}{ll}
\hline Perlakuan & \multicolumn{1}{c}{ Keterangan } \\
\hline Kontrol + & Tanpa inokulasi cendawan endofit dan mikoriza arbuskular \\
PAP4 & Inokulasi tunggal cendawan endofit kode PAP4 \\
PUP1 & Inokulasi tunggal cendawan endofit kode PUP1 \\
MA & Inokulasi tunggal mikoriza arbuskular \\
PAP4+PUP1 & Inokulasi kombinasi cendawan endofit kode PAP4 dan PUP1 \\
PAP4+MA & Inokulasi kombinasi cendawan endofit kode PAP4 dan mikoriza arbuskular \\
PUP1+MA & $\begin{array}{l}\text { Inokulasi kombinasi cendawan endofit kode PUP1 dan mikoriza arbuskular } \\
\text { PAP4+PUP1+MA } \\
\text { Inokulasi kombinasi cendawan endofit kode PAP4, PUP1 dan mikoriza } \\
\end{array}$ \\
\hline
\end{tabular}




\section{Pengamatan Kolonisasi Mikoriza Arbuskular dan Cendawan Endofit pada Akar Bawang Merah}

Sampel akar yang diamati ialah akar perlakuan semai umur 4 minggu tanpa inokulasi patogen dan akar dari perlakuan diinokulasi patogen umur 3 minggu setelah inokulasi. Hal ini dilakukan untuk melihat pengaruh kolonisasi tersebut terhadap kemampuan agens biokontrol dan pertumbuhan tanaman. Sampel akar yang telah diwarnai, dipotong sepanjang $1 \mathrm{~cm}$ dan disusun berjajar pada kaca preparat (1 kaca preparat untuk 10 potong akar). Akar diamati di bawah mikroskop compound Olympus CH3O dan akar yang terinfeksi dihitung. Pengamatan dilakukan sebanyak 3 ulangan.

Penampakan struktur hifa internal, hifa, arbuskular, vesikula, dan spora merupakan suatu indikasi bahwa akar tersebut telah terkolonisasi oleh MA. Potongan akar yang terkolonisasi cendawan endofit akan menunjukkan struktur hifa yang sesuai dengan cendawan tersebut di dalam korteks akar. Persen kolonisasi dihitung dengan rumus:

Persen kolonisasi $=\frac{\sum \text { akar terkolonisasi }}{\sum \text { akar yang diamati }} \times 100 \%$

\section{Insidensi Penyakit}

Insidensi penyakit layu fusarium diamati setiap minggu setelah inokulasi patogen dan dihitung menggunakan rumus sebagai berikut:

$$
\mathrm{IP}=\frac{\mathrm{n}}{\mathrm{N}} \times 100 \% \text {, dengan }
$$

$\mathrm{n}$, jumlah tanaman bergejala dan $\mathrm{N}$, jumlah tanaman yang diamati.

\section{Perhitungan Laju Infeksi dan Kurva Perkembangan Penyakit (AUDPC) Penyakit Layu Fusarium}

Penyakit layu fusarium ialah penyakit dengan tipe monosiklik sehingga laju infeksi (r) dihitung dengan rumus van der Plank (1964), yaitu:

$$
\mathrm{r}=\frac{\mathrm{e}}{\mathrm{t}} \times\left[\log \frac{1}{1-\mathrm{Xt}}-\log \frac{1}{1-\mathrm{Xo}}\right] \text {, dengan }
$$

e, 2.714; t, selang waktu pengamatan; Xt, Insidensi penyakit pada waktu tertentu; Xo,
Insidensi penyakit pada waktu sebelumnya. Laju perkembangan penyakitnya dihitung menggunakan rumus:

$$
\mathrm{AUDPC}=\frac{\mathrm{Xt}-\mathrm{Xo}}{2} \times \mathrm{t} \text {, dengan }
$$

$\mathrm{Xt}$, insidensi penyakit pada waktu tertentu; dan Xo, insidensi penyakit pada waktu sebelumnya.

\section{Uji Mekanisme Antagonis Cendawan Endofit terhadap $F$. oxysporum f. sp. cepae secara in Vitro}

Uji ini dilakukan menggunakan metode kultur ganda (Talapatra et al. 2017) pada medium ADK. Biakan F. oxysporum f. sp. cepae dan cendawan endofit berumur 7 hari (berdiameter $5 \mathrm{~mm}$ ) diletakkan dalam medium ADK secara berhadapan dengan jarak $3 \mathrm{~cm}$. Sebagai kontrol $F$. oxysporum f. sp. cepae ditumbuhkan pada cawan petri tanpa cendawan endofit. Zona bening dihitung setelah inkubasi 7 hari. Pengujian disusun dalam RAL yang terdiri atas 3 perlakuan dan 3 ulangan.

\section{Analisis Data}

Data kolonisasi agens biokontrol, tinggi tanaman dan jumlah daun dianalisis dengan sidik ragam (ANOVA) menggunakan program SAS versi 9.1. Perbedaan nilai antarperlakuan diuji lanjut menggunakan uji Duncan pada taraf $\alpha 5 \%$.

\section{HASIL}

Gejala layu pada tanaman kontrol muncul pada hari ke-5 setelah inokulasi. Gejala dimulai dengan menguningnya ujung daun sampai pangkal, daun meliuk layu dan nekrosis (Gambar 1).

Mikoriza arbuskular dan cendawan endofit mampu mengoloni akar tanaman bawang merah. Pengamatan terhadap kolonisasi agens biokontrol pada akar bawang merah tanpa patogen menunjukkan persentase kolonisasi MA tertinggi pada aplikasi tunggal (MA), yaitu $43.33 \%$ dan diikuti dengan aplikasi PUP1+MA sebesar 40\%. Kolonisasi agens biokontrol pada akar bawang merah dengan 
inokulasi patogen juga menunjukkan MA mempunyai persentase kolonisasi tertinggi pada aplikasi tunggal maupun kombinasi dengan endofit PUP1 berturut-turut sebesar $80 \%$ dan $83.33 \%$ (Tabel 2).

Aplikasi MA dan CE secara tunggal menunjukkan ketiga agens biokontrol tersebut mengalami peningkatan persentase kolonisasi setelah inokulasi patogen dengan persentase kolonisasi tertinggi oleh MA sebesar $43.33 \%$ menjadi $80 \%$ (Tabel 2). Hasil pewarnaan akar juga membuktikan adanya kolonisasi agens biokontrol dan bersimbiosis dengan akar tanaman bawang merah. Akar yang tidak terkolonisasi oleh patogen dan agens biokontrol tidak tampak struktur hifa atau vesikel dan akar pada perlakuan kontrol menunjukkan adanya struktur hifa dan mikrokonidia pada sel korteks dari cendawan
F. oxysporum f. sp. cepae. Kolonisasi agens biokontrol pada perlakuan aplikasi tunggal cendawan endofit PAP4 menunjukkan adanya kolonisasi hifa berseptat pada sel korteks akar. Hifa intraseluler tampak pada korteks akar yang diberi perlakuan PUP1, sedangkan hifa dan vesikula terminal tampak pada perlakuan tunggal MA (Gambar 2).

Perlakuan agens biokontrol secara kombinasi juga menunjukkan ketiga agens mampu berkolonisasi dalamjaringan akar.Pada perlakuan MA persen kolonisasi meningkat setelah inokulasi patogen, tertinggi pada perlakuan kombinasi dengan PUP1, yaitu 40\% menjadi $83.33 \%$, sedangkan untuk perlakuan cendawan endofit keduanya cenderung turun setelah diinokulasi patogen. Akan tetapi, untuk perlakuan kombinasi ketiga agens biokontrol tampak meningkat setelah diinokulasi patogen

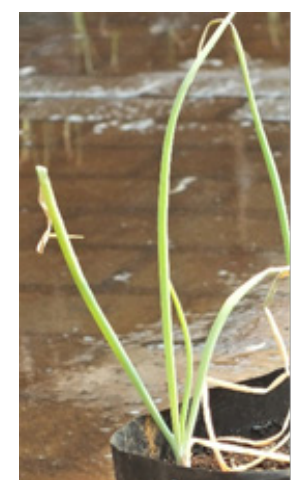

a

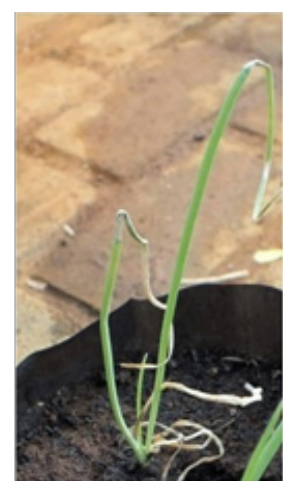

b

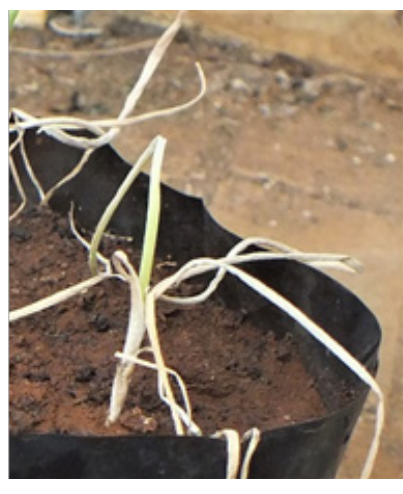

c

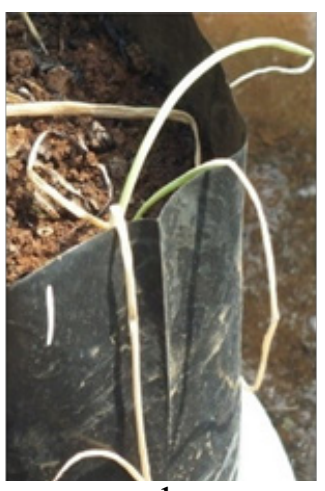

d

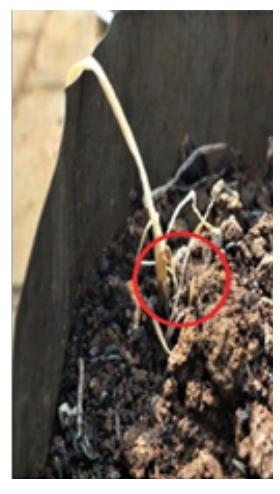

e

Gambar 1 Keragaman gejala penyakit layu fusarium pada tanaman kontrol bawang merah varietas Tuk-tuk yang diuji. a, Daun layu dan menguning; b dan c, Daun layu dan ujung daun klorosis; d dan e, Basal plate busuk, daun klorosis, mengering, dan tanaman akhirnya mati.

Tabel 2 Pengaruh kolonisasi perlakuan mikoriza arbuskular dan cendawan endofit pada akar bawang merah

\begin{tabular}{|c|c|c|c|c|c|c|}
\hline \multirow{3}{*}{ Perlakuan } & \multicolumn{6}{|c|}{ Kolonisasi (\%) } \\
\hline & \multicolumn{3}{|c|}{ Tanpa patogen } & \multicolumn{3}{|c|}{ Inokulasi patogen } \\
\hline & MA & PAP4 & PUP1 & MA & PAP4 & PUP1 \\
\hline PAP4 & - & $33.33 \mathrm{a}$ & - & - & $60.00 \mathrm{a}$ & - \\
\hline PUP1 & - & - & $26.67 \mathrm{a}$ & - & - & $50.00 \mathrm{a}$ \\
\hline MA & $43.33 \mathrm{a}$ & - & - & $80.00 \mathrm{a}$ & - & - \\
\hline PAP4+PUP1 & - & $26.67 \mathrm{bc}$ & $30.00 \mathrm{a}$ & - & $20.00 \mathrm{c}$ & $23.33 \mathrm{c}$ \\
\hline PAP4+MA & $36.67 \mathrm{~b}$ & $30.00 \mathrm{ab}$ & - & $50.00 \mathrm{~b}$ & $40.00 \mathrm{~b}$ & - \\
\hline PUP1+MA & $40.00 \mathrm{ab}$ & - & $33.33 \mathrm{a}$ & $83.33 \mathrm{a}$ & - & $23.33 \mathrm{c}$ \\
\hline PAP4+PUP1+MA & $36.67 \mathrm{~b}$ & $23.33 \mathrm{c}$ & $26.67 \mathrm{a}$ & $80.00 \mathrm{a}$ & $33.33 \mathrm{~b}$ & $40.00 \mathrm{~b}$ \\
\hline
\end{tabular}

Angka selajur yang diikuti huruf yang berbeda menunjukkan perbedaan nyata pada uji jarak berganda Duncan (DMRT) $\propto 5 \%$.

- = tidak diaplikasikan agens biokontrol tersebut. 
(Tabel 2). Pewarnaan akar menunjukkan pada perlakuan kombinasi PAP4 dan PUP1 terdapat hifa septat dan aseptat dalam korteks akar secara intraseluler (Gambar 3b); kombinasi PAP4 dan MA terdapat struktur MA berupa hifa dan vesikula, hifa septat dalam korteks akar. Koloni hifa endofit PAP4 lebih sedikit dibanding koloni MA (Gambar 3c); kombinasi PUP1 dan MA terdapat hifa aseptat, hifa internal dan vesikula MA (Gambar 3d), dan kombinasi PAP4, PUP1, dan MA terdapat hifa septat, hifa aseptat, hifa internal dan vesikula MA (Gambar 3e).

Kolonisasi agens biokontrol yang diaplikasikan berpengaruh terhadap pertumbuhan bawang merah. Tinggi tanaman berbeda nyata pada perlakuan aplikasi tunggal MA dan pada perlakuan kombinasi PUP1+MA tanpa patogen dan inokulasi patogen, sedangkan pada jumlah helai daun berbeda nyata pada aplikasi MA secara tunggal (Tabel 3).

Pengendalian yang efektif juga didukung dari lamanya periode laten penyakit, rendahnya insidensi penyakit, dan lambatnya laju infeksi penyakit (Tabel 4). Aplikasi agens biokontrol memengaruhi periode laten, insidensi penyakit, laju infeksi, dan kurva perkembangan penyakit (AUDPC). Bila AUDPC nilainya besar artinya penyakit layu fusarium berkembang lebih cepat. Ratarata periode laten $F$. oxysporum f. sp. cepae dalam menginfeksi ialah 7 hari. Periode laten

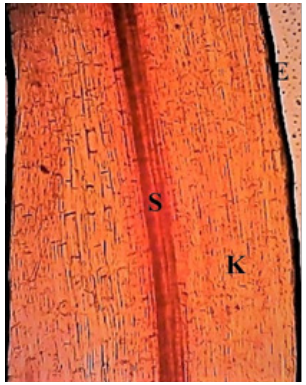

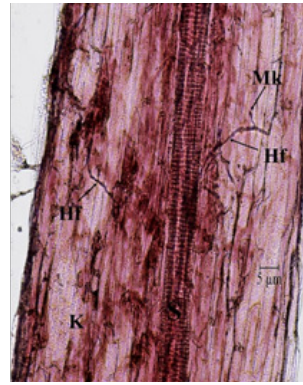

b

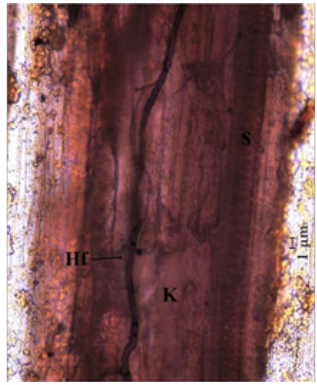

C

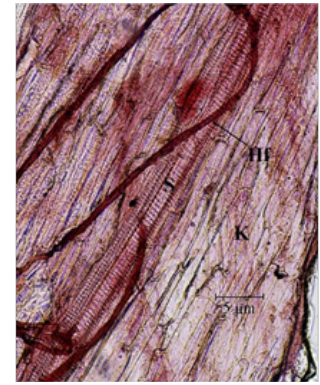

d

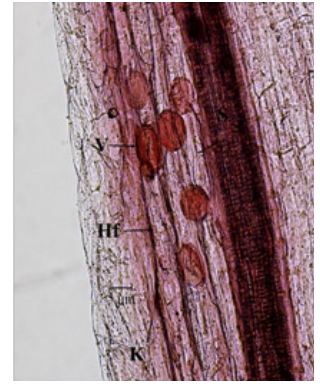

e

Gambar 2 Jaringan akar tanaman bawang merah pada perlakuan kontrol dan aplikasi tunggal mikoriza arbuskular dan cendawan endofit. a, Akar tidak terkolonisasi patogen atau agens biokontrol; b, Kolonisasi F. oxysporum f. sp. cepae pada perlakuan kontrol; c, Kolonisasi cendawan endofit perlakuan PAP4; d, Kolonisasi cendawan endofit perlakuan PUP1; dan e, Kolonisasi tunggal MA. Gambar a, d, dan e diamati pada pebesaran 20×, sedangkan $b$ dan c pada perbesaran $40 \times \mathrm{E}=$ epidermis; $\mathrm{Hf}=$ hifa; $\mathrm{K}=$ korteks; $\mathrm{Mk}=$ mikrokonidia; $\mathrm{S}=$ stele; dan $\mathrm{V}=$ vesikula.

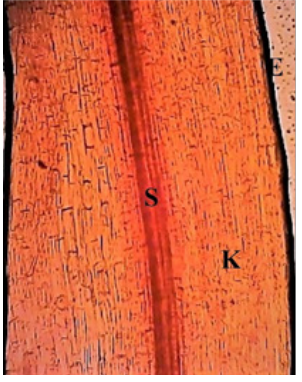

a

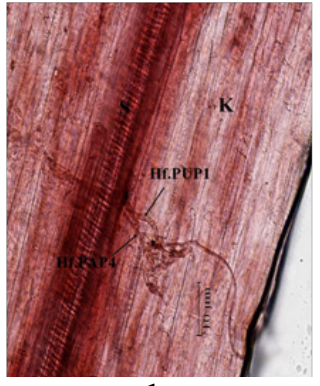

b

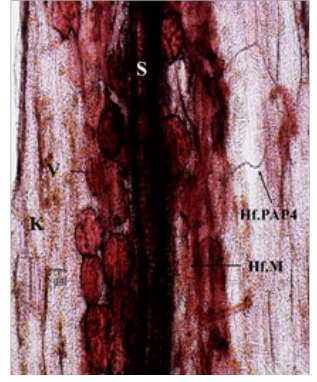

$\mathrm{C}$

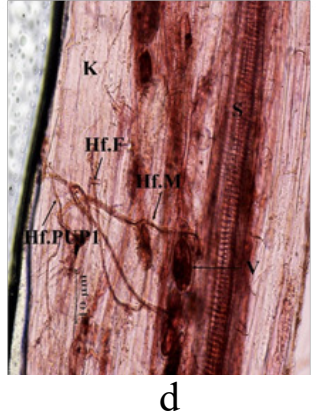

d

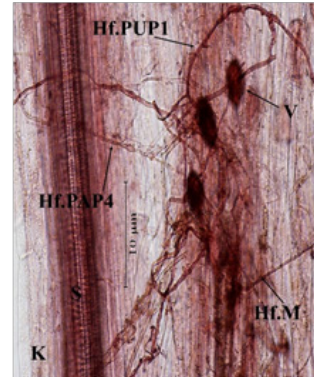

e

Gambar 3 Jaringan akar tanaman bawang merah pada perlakuan kombinasi mikoriza arbuskular dan cendawan endofit: (a) akar yang tidak terkolonisasi agens biokontrol, (b) kolonisasi cendawan endofit PAP4 dan PUP1, (c) kolonisasi PAP4 dan MA, (d) kolonisasi PAP4 dan MA dan (e) kolonisasi PAP4, PUP1, dan MA. Perbesaran yang digunakan (a), (b), (c), (d), dan (e): 20x. Simbol E: epidermis, Hf: hifa, Hf.F: hifa F. oxysporum f. sp. cepae, Hf.M: hifa MA, K: korteks, S: stele, dan V: vesikula 
terpanjang, yaitu 21 hari ditunjukkan oleh perlakuan tunggal MA dan dikuti perlakuan kombinasi PUP1+MAselama 18 hari(Tabel4). Perlakuan agens biokontrol MA secara tunggal mampu menurunkan insidensi penyakit sampai $40 \%$ dan pada perlakuan kombinasi PUP1 dan MA menurunkan insidensi penyakit sebesar $33.3 \%$ pada gejala visual. Perlakuan F. oxysporum f. sp. cepae tanpa MA dan CE semua tanaman terinfeksi $100 \%$ (Tabel 4). Perlakuan paling baik dalam menekan layu fusarium berdasarkan parameter uji ialah MA.

Hasil pengujian mekanisme antagonisme dari cendawan endofit yang diuji ialah antibiosis (Tabel 5). Zona bening terlebar ditunjukkan cendawan endofit PAP4 sebesar
$1.83 \mathrm{~mm}$ (Tabel 5 dan Gambar 4). Zona bening yang terbentuk karena cendawan endofit menghasilkan metabolit untuk menghambat pertumbuhan patogen.

Bentuk simbiosis yang terjadi di antara agens biokontrol yang diuji ialah independen, antagonis, netral dan amensalisme (Tabel 6). Bentuk simbiosis agens biokontrol tersebut berdasarkan data persentase kolonisasi agens biokontrol yang diujikan (Tabel 2) dan pengaruhnya terhadap penekanan layu fusarium berdasarkan periode laten, insidensi penyakit, laju infeksi dan kurva perkembangan penyakit layu fusarium (Tabel 4). Perlakuan tunggal agens biokontrol MA, cendawan endofit PAP4, dan cendawan endofit

Tabel 3 Pengaruh perlakuan agens biokontrol terhadap tinggi tanaman dan jumlah daun tanaman bawang merah

\begin{tabular}{lccccc}
\hline \multirow{2}{*}{ Perlakuan } & \multicolumn{2}{c}{ Tinggi tanaman $(\mathrm{cm})$} & & \multicolumn{2}{c}{ Jumlah daun (helai) } \\
\cline { 2 - 3 } \cline { 5 - 6 } & Tanpa patogen & Inokulasi patogen & & Tanpa patogen & Inokulasi patogen \\
\hline Kontrol & $18.40 \mathrm{~b}$ & $17.05 \mathrm{e}$ & & $3.00 \mathrm{~b}$ & $5.40 \mathrm{~b}$ \\
PAP4 & $19.20 \mathrm{~b}$ & $21.61 \mathrm{de}$ & & $3.20 \mathrm{ab}$ & $5.13 \mathrm{bc}$ \\
PUP1 & $19.20 \mathrm{~b}$ & $24.67 \mathrm{~cd}$ & & $3.00 \mathrm{~b}$ & $5.13 \mathrm{bc}$ \\
MA & $22.90 \mathrm{a}$ & $35.30 \mathrm{a}$ & & $3.60 \mathrm{a}$ & $6.73 \mathrm{a}$ \\
PAP4+PUP1 & $19.30 \mathrm{~b}$ & $22.07 \mathrm{de}$ & & $3.00 \mathrm{~b}$ & $4.73 \mathrm{c}$ \\
PAP4+MA & $19.10 \mathrm{~b}$ & $29.10 \mathrm{bc}$ & & $3.20 \mathrm{ab}$ & $5.80 \mathrm{~b}$ \\
PUP1+MA & $22.80 \mathrm{a}$ & $33.52 \mathrm{ab}$ & & $3.40 \mathrm{ab}$ & $5.73 \mathrm{~b}$ \\
PAP4+PUP1+MA & $18.70 \mathrm{~b}$ & $28.05 \mathrm{bc}$ & & $3.00 \mathrm{~b}$ & $5.33 \mathrm{~b}$ \\
\hline
\end{tabular}

Angka selajur yang diikuti huruf yang berbeda menunjukkan perbedaan nyata pada uji jarak berganda Duncan (DMRT) $\alpha 5 \%$.

Tabel 4 Pengaruh perlakuan agens biokontrol terhadap periode laten, insidensi penyakit, laju infeksi (r), dan kurva perkembangan penyakit layu Fusarium bawang merah (AUDPC)

\begin{tabular}{lcccc}
\hline Perlakuan & $\begin{array}{c}\text { Periode laten } \\
\text { (hari) }\end{array}$ & $\begin{array}{c}\text { Insidensi penyakit } \\
(\%)\end{array}$ & $\mathrm{r}$ & AUDPC \\
\hline Kontrol + & 7.5 & 100.0 & 1.00 & 256.55 \\
PAP4 & 17.5 & 86.7 & 0.14 & 303.45 \\
PUP1 & 11.0 & 86.7 & 0.14 & 303.45 \\
MA & 21.0 & 60.0 & 0.07 & 210.00 \\
PAP4+PUP1 & 13.5 & 80.0 & 0.10 & 256.55 \\
PAP4+MA & 13.3 & 73.3 & 0.09 & 256.55 \\
PUP1+MA & 18.5 & 66.7 & 0.08 & 233.45 \\
PAP4+PUP1+MA & 16.5 & 86.7 & 0.14 & 303.45 \\
\hline
\end{tabular}

Tabel 5 Pengaruh cendawan endofit terhadap pertumbuhan F.oxysporum f.sp. cepae secara in vitro

\begin{tabular}{lcc}
\hline Kode isolat endofit & Interaksi & Lebar zona bening \\
\hline PAP4 & antibiosis & $1.83 \mathrm{~mm}$ \\
PUP1 & antibiosis & $0.67 \mathrm{~mm}$ \\
\hline
\end{tabular}


PUP1 terjadi secara independen. Perlakuan kombinasi cendawan endofit PAP4+PUP1 dan PAP4+PUP1+MA terjadi secara antagonis, PAP4+MA netral, sedangkan PUP1+MA secara amensalisme. Pengaruh perlakuan agens biokontrol terhadap penekanan layu

a

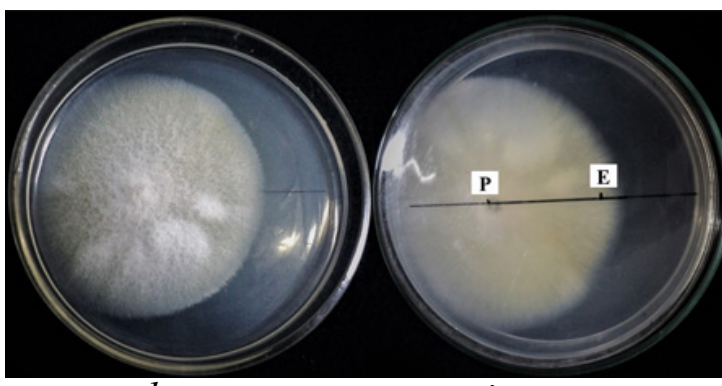

adverse

inverse

b

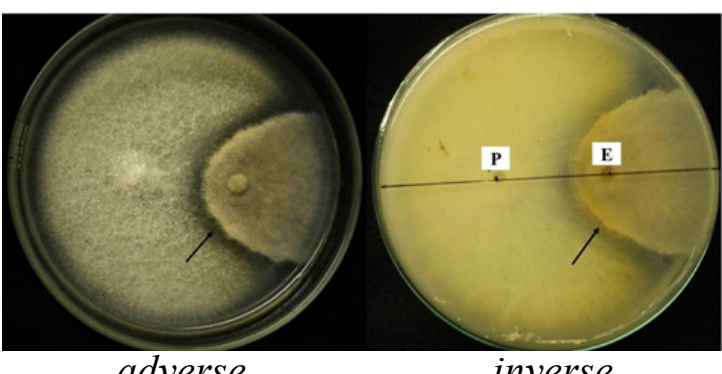

adverse

inverse

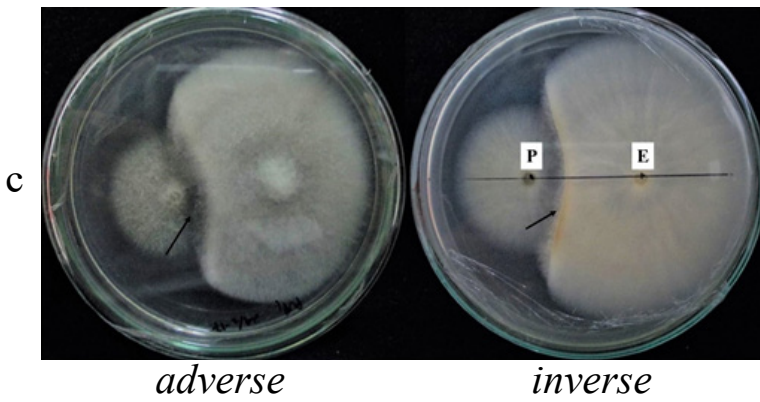

Gambar 4 Uji kultur ganda cendawan endofit terhadap $F$. oxysporum f.sp. cepae dengan (a) perlakuan kontrol $F$. oxysporum f. sp. cepae tanpa cendawan endofit, (b) perlakuan cendawan endofit PAP4, dan (c) perlakuan cendawan endofit PUP1 fusarium dikelompokan menjadi lemah, sedang, dan kuat (Tabel 6). Perlakuan tunggal agens biokontrol MA mempunyai pengaruh kuat terhadap penekanan layu fusarium.

\section{PEMBAHASAN}

Gejala layu fusarium pada bawang merah oleh $F$. oxysporum ialah daun menguning pada pucuk daun ke arah pangkal daun. Bentuk daun menjadi rata dan tebal sedangkan daun normal berbentuk seperti pipa, daun tidak tumbuh tegak tetapi meliuk karena daun tumbuh lebih panjang, serta warna daun hijau pucat atau kekuningan (Tondok 2001). Kemampuan kolonisasi agens biokontrol pada jaringan tanaman, dapat membuktikan adanya interaksi agens biokontrol dengan tanaman. Selain aplikasi agens biokontrol tunggal, dalam penelitian ini juga dilakukan secara kombinasi antar agens biokontrol.

Tondok (2001) dalam penelitiannya melaporkan periode munculnya gejala penyakit akibat $F$. oxysporum isolat CRB 13 pada bibit bawang merah dengan pengujian di Bogor dan Cirebon membutuhkan waktu 5-6 hari. Hal ini sesuai dengan hasil penelitian ini yang menunjukkan periode laten 5-12 hari. Namun, Zulaika (2014) melaporkan gejala penyakit yang ditimbulkan $F$. oxysporum mulai tampak pada hari ke-3 setelah inokulasi patogen. Gejala layu dan menguning yang terjadi pada tanaman bawang merah diduga merupakan gejala sekunder yang diakibatkan oleh terganggunya sistem transportasi air dari akar ke seluruh tanaman. Perubahan warna menguning dapat disebabkan oleh adanya penurunan kloroplas akibat gangguan yang

Tabel 6 Bentuk simbiosis yang terjadi antar agens biokontrol yang diuji dan pengaruhnya terhadap penekanan layu fusarium

\begin{tabular}{lcc}
\hline Agens biokontrol & Bentuk simbiosis antaragens & Pengaruh terhadap penekanan layu fusarium \\
\hline PAP4 & Independen & Lemah \\
PUP1 & Independen & Lemah \\
MA & Independen & Kuat \\
PAP4 + PUP1 & Antagonis & Lemah \\
PAP4+MA & Netral & Sedang \\
PUP1+MA & Amensalisme & Sedang \\
PAP4+PUP1+MA & Antagonis & Lemah \\
\hline
\end{tabular}


disebabkan oleh patogen yang menyebabkan kandungan klorofil pada daun menurun. Fusarium sp. diketahui menghasilkan senyawa metabolik yang toksik pada tanaman dan tidak spesifik pada inang yang disebut asam fusarat yang menyebabkan warna kuning pada daun (Agrios 2005). Leslie dan Summerell (2006) menambahkan Fusarium sp. mempunyai toksin utama fumosinin dan trichotcenes yang dapat menyebabkan jaringan basal plate dan umbi membusuk.

Agens biokontrol cendawan endofit (PAP4 dan PUP1) dan MA yang digunakan dalam penelitian diketahui bersimbiosis dengan inang dan mengoloni jaringan akar sama halnya dengan cendawan $F$. oxysporum f. sp. cepae pada perlakuan kontrol. Fusarium penyebab layu fusarium perkembangannya dapat ditekan oleh agens biokontrol apabila telah terjadi simbiosis antara tanaman inang terlebih dahulu. Jika patogen menginfeksi tanaman sebelum kolonisasi agens biokontrol, maka agens biokontrol tidak dapat berkembang dan berfungsi sebagai penekan dalam perkembangan cendawan patogen pada tanaman inang. Interaksi antara agens biokontrol dengan tanaman dapat bersifat netral, sinergis, dan negatif. Interaksi mutualisme antara tanaman dan cendawan dapat meningkatkan pertumbuhan inang dan ketahanan terhadap patogen. Menurut Zuccaro et al. (2014), kolonisasi cendawan dengan akar menunjukkan fungsi penting dalam penyerapan hara mineral oleh inang, siklus karbon, meningkatkan pertumbuhan tanaman, dan meningkatkan ketahanan terhadap patogen tanaman yang menjadi dasar dalam produktivitas tanaman.

MA dan CE yang masuk pada jaringan tanaman diharapkan mampu berkolonisasi dan dapat menekan perkembangan penyakit pada tanaman dengan menginduksi ketahanan tanaman. Muller (2015) menerangkan bahwa tumbuhan dan mikroorganisme endofit berinteraksi secara berkelanjutan di alam dalam simbiosisnya. Interaksi metabolisme terjadi dalam beberapa hal: (a) endofit menginduksi metabolisme inang, (b) inang menginduksi metabolisme endofit, (c) inang dan endofit saling mengambil bagian dalam jalur tertentu atau sebagian, (d) inang dapat memetabolisme produk dari endofit dan sebaliknya, dan (e) endofit dapat memetabolisme senyawa sekunder dari inang seperti senyawa fenol.

Koloni MA pada akar terlihat adanya hifa internal, hifa eksternal, dan vesikula. Brundrett et al. (1996) menerangkan MA mempunyai hifa eksternal, internal, coil, vesikula dan arbuskular. Hifanya tidak bersekat dan tumbuh secara intra dan interseluler dalam sel korteks akar dan bercabang-cabang. Proses kolonisasi MA pada akar tanaman dimulai dari adanya kontak antara hifa MA yang berasal dari sporokarp, zigospora atau komponen lainnya yang terdapat di sekitar perakaran inang. Penetrasi dimulai dengan pembentukan apresorium untuk melekatkan diri pada inang. Selanjutnya hifa akan menembus sel-sel korteks akar melalui sel epidermis rambut akar, setelah mecapai bagian tengah korteks, tumbuh secara interseluler, intraseluler dan keduanya. Hifa MA tidak masuk ke jaringan stele dan hifa yang bergelembung bercabangcabang disebut arbuskular. Arbuskular diduga berfungi sebagai struktur transfer unsur hara dalam jaringan tanaman. Pada struktur yang menggelembung ibentuk secara apikal dan sering terdapat pada hifa utama disebut vesikula. Vesikula ukurannya kadang besar dan berdinding tebal serta mengandung banyak lipid, berfungsi sebagai organ simpan. Apabila korteks mengelupas, beberapa vesikula dapat berkecambah dan menjadi propagul infektif di dalam tanah. Dalam penelitian ini tidak ditemukan struktur arbuskular diduga karena saat pengambilan sampel akar tanaman dalam kondisi kering dan MA lebih banyak membentuk struktur vesikula.

Sedangkan koloni cendawan endofit PAP4 berupa hifa septat dan endofit PUP1 berupa hifa tidak bersekat yang mengoloni sel korteks secara intraseluler. Hal ini karena cendawan endofit yang digunakan merupakan hifa steril. Menurut Fesel dan Zuccaro (2016), strategi kolonisasi cendawan endofit pada akar ialah endofit mengoloni secara interseluler pada epidermis dan korteks akar secara intraseluler, di dalam korteks akar hifa berkoloni 
memperbanyak diri. Kolonisasi cendawan endofit hanya terjadi di daerah epidermis dan sel-sel korteks akar dan hifa tidak ditemukan di dalam endodermis dan jaringan stele.

Perlakuan aplikasi MA baik secara tunggal maupun kombinasi mempunyai persen kolonisasi yang tinggi. Aplikasi agens tunggal MA mampu menghambat penekanan layu fusarium paling baik. MA dilaporkan mempunyai bakteri endosimbiotik yang bersimbiosis dengan mikoriza yang dapat memacu perkecambahan spora MA, meningkatkan penyerapan hara, dan menekan pertumbuhan patogen (Bakhtiar 2011; Cruz dan Ishii 2012; Khairani et al. 2017). Bakteri endosimbiotik mikoriza Bacillus subtilis B10 dilaporkan memiliki aktivitas menghambat pertumbuhan patogen $G$. boninense secara in vitro (Bakhtiar et al. 2010). MA mempunyai penekanan terhadap layu fusarium paling baik dapat dikarenakan MA menstimulasi pertahanan tanaman bawang merah terhadap patogen Fusarium. Al-Askar dan Rashad (2010) dalam penelitiannya melaporkan kolonisasi MA dapat menurunkan persen keparahan penyakit dan insidensi penyakit busuk akar yang disebabkan oleh $F$. solani yang ditunjukkan dengan adanya peningkatan yang signifikan terhadap kandungan senyawa fenol dan aktivitas enzim pertahanan polyphenoloxidase (PPO), enzim peroxidase (POD), dan enzim phenylalanine ammonialyase (PAL) pada tanaman bean.

Bentuk simbiosis antar mikroorganisme dalam habitatnya dapat bersifat netral, mutualisme, parasitisme, komensalisme, predasi dan amensalisme. Dalam penelitian ini agens biokontrol yang diujikan saling dikombinasikan. Menurut $\mathrm{Xu}$ et al. (2011) adanya kombinasi antara beberapa agens biokontrol dapat bersifat independen, sinergis, maupun antagonis. Hal ini untuk menjelaskan bahwa antara agens biokontrol yang mengolonisasi jaringan tanaman dan patogen yang diinokulasikan dapat menyebabkan berbagai kemungkinan seperti: keduanya tidak saling memengaruhi, saling berkompetisi, sinergis dalam menimbulkan gejala penyakit atau menekan insidensi penyakit.
Bentuk simbiosis yang terjadi antar agens biokontrol yang diuji dalam penelitian ialah independen, antagonis, netral dan amensalisme. Berdasarkan persentase kolonisasi agens biokontrol menunjukkan bentuk simbiosis independen terjadi pada aplikasi tunggal agens biokontrol MA, cendawan endofit PAP4 , dan cendawan endofit PUP1. Perlakuan kombinasi agens biokontrol PAP4+PUP1 dan PAP4+PUP1+MA terjadi secara antagonis, yaitu agens biokontrol saling berkompetisi terhadap ruang tumbuh dan nutrisi, PAP4+MA bersifat netral yaitu tidak saling mempengaruhi, sedangkan PUP1+MA secara amensalisme yaitu agen biokontrol PUP1 pertumbuhannya terhambat dibandingkan dengan agen MA. Perlakuan agens biokontrol dan simbiosisnya berpengaruh lemah, sedang, dan kuat terhadap penekanan layu fusarium. Perlakuan tunggal agen biokontrol MA mempunyai pengaruh kuat terhadap penekanan layu fusarium.

Aplikasi mikoriza arbuskular secara tunggal mempunyai kefektifan pengendalian lebih tinggi dibandingkan dengan kombinasi dengan cendawan endofit. Mikoriza arbuskular berhasil mengoloni akar bawang merah dengan baik, memperpanjang periode laten, menurunkan insidensi penyakit dan nyata meningkatkan pertumbuhan tanaman.

\section{UCAPAN TERIMAKASIH}

Ucapan terima kasih disampaikan kepada Ditjen DIKTI yang membantu dana penelitian ini melalui Beasiswa BPP-DN 2013.

\section{DAFTAR PUSTAKA}

Agrios GN. 2005. Plant Pathology. Ed ke5. California (US): Elsevier Academic Pr. Al-Askar AA, Rashad YM. 2010. Arbuscular mycorrhizal fungi: Biocontrol agent against common bean Fusarium root rot disease. Plant Pathol J. 9(1):31-38. DOI: https://doi.org/10.3923/ppj.2010.31.38.

Bakhtiar Y, Yahya S, Sumaryono W, Sinaga MS, Budi SW, Tajuddin T. 2010. Isolation and identification of mycorrhizosphere bacteria and their antagonistic effect 
towards Ganoderma boninense in vitro. Microbiol Indones. 4:96-102. DOI: https:// doi.org/10.5454/mi.4.2.9.

Bakhtiar Y. 2011. Peran fungi mikoriza arbuskular dan bakteri endosimbiotik mikoriza dalam meningkatkan daya adaptasi bibit kelapa sawit (Elaeis guineensis Jacq) terhadap cekaman biotik Ganoderma boninense Pat [disertasi]. Bogor (ID): Institut Pertanian Bogor.

Brundrett M, Bougher N, Dell B, Grove T, Malajczuk N. 1996. Working With Mycorrhizas In Forestry and Agriculture (No. 435-2016-33680). Canberra (AU): Australian Centre for International Agricultural Research.

Cruz AF, Ishii T. 2012. Arbuscular mycorrhizal fungal spores host bacteria that affect nutrient biodynamics and biocontrol of soilborne plant pathogens. Biol Open. 1:52-57. DOI: https://doi.org/10.1242/bio.2011014.

Fadhilah S, Wiyono S, Surahman. 2014. Pengembangan Teknik Deteksi Fusarium Patogen Pada Umbi Benih Bawang Merah (Allium ascalonicum) di Laboratorium. J Horti. 24(2):171-178. DOI: https://doi. org/10.21082/jhort.v24n2.2014.p171-178.

Fesel PH, Zuccaro A. 2016. Dissecting endophytic lifestyle along the parasitism/ mutualism continuum in Arabidopsis. Curr Opin Microbiol. 32:103-112. DOI: https:// doi.org/10.1016/j.mib.2016.05.008.

Khairani HG, Sinaga MS, Mutaqin KH. 2017. Mekanisme pengendalian penyakit busuk batang jeruk oleh khamir, kitosan, cendawan mikoriza arbuskular, dan bakteri simbiotiknya. J Fitopatol Indones.13(1):17-25. DOI: https://doi. org/10.14692/jfi.13.1.

Leslie JF, Summerell BA, Bullock S. 2006. The Fusarium laboratory manual. Manhattan (US): Blackwell Publishing. DOI: https:// doi.org/10.1002/9780470278376.

Muller JL. 2015. Plants and endophytes: equal partners in secondary metabolite production?. Biotechnol Lett. DOI: https:// doi.org/10.1007/s10529-015-1814-4.

Ozgönen H, Akgul DS, Erkilic A. 2010. The effects of arbuscular mycorrhizal fungi on yield and stem rot caused by Sclerotium rolfsii Sacc. in peanut. African J Agric Res. 5(2):128-132.

Priyadharsini P, Pandey RR, Muthukumar T. 2012. Arbuscular mycorrhizal and dark septate fungal associations in shallot (Allium cepa L. var. aggregatum) under conventional agriculture. Acta Bot Croat. 71(1):159-175. DOI: https://doi. org/10.2478/v10184-011-0058-1.

Talapatra K, Das AR, Saha AK, Das P. 2017. In vitro antagonistic activity of a root endophytic fungus towards plant pathogenic fungi. J App Biol Biotech. 5(2):68-71. DOI: https://doi.org/10.7324/ JABB.2017.50210.

Tondok ET. 2001. Twisting disease caused by Fusarium oxysporum on shallot (Allium cepa L. var. agregatum G. Don.) in Indonesia. [thesis]. Jerman (DE): Institute of Plant Protection, Faculty of Agriculture, George-August University Geottingen, Germany.

Wiyatiningsih S, Arif W, Endang TP. 2009. Keparahan penyakit moler pada enam kultivar bawang merah karena infeksi Fusarium oxysporum f.sp. cepae di tiga daerah sentra produksi. Seminar Nasional Akselerasi Pengembangan Teknologi Pertanian dalam Mendukung Revitalisasi Pertanian. 2009 Des 2. Surabaya (ID). Fak. Pertanian dan LPPM UPN Veteran Jawa Timur.

Xu XM, Jeffries P, Pautasso M, Jegger MJ. 2011. Combined use of biocontrol agent to manage plant disease in theory and practice. Phytopathology 1001(9):10241031. DOI: https://doi.org/10.1094/ PHYTO-08-10-0216.

Zuccaro A, Lahrmann U, Langen G. 2014. Broad compatibility in fungal root symbioses. Curr Opin Plant Biol. 20:135145. DOI: https://doi.org/10.1016/j. pbi.2014.05.013.

Zulaika. 2014. Pemanfaatan cendawan endofit dalam pengendalian busuk umbi (Fusarium oxysporum) pada bawang merah (Allium cepa var. aggregatum) [skripsi]. Bogor (ID):Institut Pertanian Bogor. 